\title{
Description of UMKMs in Bandar Lampung City using e- filing in paying taxes in pandemic period
}

\author{
Maryani Maryani ${ }^{1}$, Damayanti Damayanti ${ }^{{ }^{*}}$ and EY Puspitasari ${ }^{2}$ \\ ${ }^{1}$ Program Studi Akuntansi Perpajakan, Politeknik Negeri Lampung, Bandar Lampung, \\ Indonesia \\ ${ }^{2}$ Program Studi Akuntansi, Politeknik Negeri Lampung, Bandar Lampung, Indonesia
}

*Corresponding author: damayanti@polinela.ac.id

\begin{abstract}
This study looks at an overview of how UMKMs in Bandar Lampung City use efiling in paying taxes during the Covid-19 pandemic. It studies what factors becoming indicators of UMKMs using e-filing in paying taxes. In addition to UMKMs' understanding of e-filing, the ease factor also becomes an indicator of the research. The subject of the research is all UMKMs in Bandar Lampung City regardless of whether they are registered in certain KPPs. The data obtained is based on the results of interviews and questionnaires that must be fulfilled by UMKMs. Of the 202 questionnaires distributed to 202 respondents, 152 questionnaires were returned and 111 questionnaires were analyzed. Of the 111 respondents who used e-filing in paying taxes, 65 respondents used e-filing and 46 respondents did not use e-filing.
\end{abstract}

\section{Introduction}

The Directorate General of Taxes reported that until March 31, 2018, the taxpayers' annual SPT reports that reported taxes were just $64 \%$ of the target. The Head of Regional Tax Office for Bengkulu and Lampung in kumparan.com (2018) also stated that for the past five years the target set by the Regional Tax Office has not been achieved. In 2018, until the end of October 10.4 trillion had been realized or only $69 \%$ of the set target. The target was not achieved due to many factors, such as low taxpayer awareness and compliance and other factors. Damayanti (2014) also stated that public awareness to pay taxes on time is not optimum, even many people do not pay taxes.

Damayanti (2015) and Rony Bako in Kontan Daily (2013) stated that in addition to increasing the number of new taxpayers, the Directorate General of Taxes also increased the awareness of taxpayers to report their taxes. The awareness of taxpayers in paying their taxes is needed because regional financial management comes from tax revenues. Here taxpayer compliance becomes an important aspect, therefore the government is updating the tax collection system, which was previously an official assessment system to become a self-assessment system. The self-assessment system is the submission of an annual notification letter (SPT) through an online system or e-filing. By using the efiling system, taxpayers can prepare reports and pay their taxes online. Besides, the benefits obtained by taxpayers in using e-filing are faster reporting, an increase in accuracy and efficiency, and cost reduction. E-filing makes it easier for taxpayers to submit SPT without having to come to the Tax Office. CNN Indonesia media in Ridwansyah (2018) stated that taxpayers who report SPT by e-filing show a greater number than taxpayers who report SPT manually, even though the taxpayer compliance 
level is still below $60 \%$. Based on the data obtained from the Department of Cooperatives and UMKM in Lampung Province in 2013, there were 375,415 UMKM units in Lampung. Based on UMKM monitoring data (2016) in Nurmala (2019), there were 39,960 UMKMs in Bandar Lampung City. The data is shown in table 1 below.

Table 1. Monitoring Data of UMKMs in Bandar Lampung City per District in 2016

\begin{tabular}{clc}
\hline No & Names of Districts & Number of UMKMs \\
\hline 1 & Tanjung Karang Pusat & 2.201 \\
2 & Tanjung Karang Timur & 1.814 \\
3 & Tanjung Karang Barat & 1.846 \\
4 & Kedaton & 2.086 \\
5 & Rajabasa & 1.949 \\
6 & Tanjung Seneng & 2.099 \\
7 & Sukarame & 2.172 \\
8 & Sukabumi & 1.925 \\
9 & Panjang & 2.186 \\
10 & Teluk Betung Selatan & 2.008 \\
11 & TelukBetung Barat & 1.838 \\
12 & Teluk Betung Utara & 1.879 \\
13 & Kemiling & 2.052 \\
14 & Teluk Betung Timur & 2.028 \\
15 & Enggal & 2.082 \\
16 & Bumi Waras & 1.917 \\
17 & Way Halim & 1.906 \\
18 & Kedamaian & 1.982 \\
19 & Labuhan Ratu & 2.046 \\
20 & Langkapura & 1.944 \\
& Number of UMKMs in Bandar Lampung City & 39.960 \\
\hline
\end{tabular}

Sources: Lakip Diskoperindag of Bandar Lampung City, 2016

Based on Table 1, the Cooperative Office states that of the 39,960 existing UMKMs, only $65 \%$ of UMKMs have financial reports and report taxes. It is questioned whether this is what causes UMKMs to be reluctant to pay their taxes, especially in understanding and using e-filing. Similarly, in the research of Widiyasnesti (2016) and Situmorang (2019), it is stated that the awareness of taxpayers to report taxes is quite high but the use of e-filing is still low. This is because many taxpayers have expressed difficulties in using e-filing. The Covid-19 pandemic in 2020 is a tough year for the Indonesian nation, which has a big impact on health and the economy. In the health sector, day by day more Indonesians are exposed to Covid-19, although many have recovered. In the economic sector, this pandemic has slowed down economic growth. This can be seen from the number of businesses that have closed, employees who have been laid off, and the target of economic growth in early 2020 of 5.3\% with an inflation rate of 3.1\% was not realized (Kurniawan, 2020). Based on this description, the researchers felt it was important to see how the description of UMKMs in the Bandar Lampung City used e-filing in paying taxes during the Covid-19 pandemic. The purpose of this study is to see an overview of UMKMs in Bandar Lampung City using e-filing in paying taxes during the Covid-19 pandemic.

This research is the development of research by Damayanti (2014) who researched in Sukabumi District in Bandar Lampung. The result shows that the level of public awareness to pay taxes on time is still far from good, some even do not pay taxes. The difference in this study is observing whether the use of e-filing applications increases the awareness of paying taxes as well as investigating what factors make UMKMs use e-filing applications. Here are some of the studies that have been conducted. 
1. Nurmala (2019) states that the high level of awareness of UMKMs in Bandar Lampung City in paying taxes for Kedaton and Rajabasa is influenced jointly by knowledge, level of trust, tax sanctions, tax payment system, ownership of corporate NPWP, and level of education.

2. Firdaus (2019) states that the quality and ease of use of e-filing applications affects taxpayers in paying their taxes.

3. Ridwansyah, Eksa, and Damayanti (2018) states that the use of e-filing is influenced by perceptions of usefulness, convenience, and attitude.

\section{Methods}

\subsection{Research Subject}

The subject of this research is the UMKM which is registered in the monitoring data of the Cooperative, UMKM, Industry and Trade Office of Bandar Lampung, especially UMKMs in Kedaton and Rajabasa districts, Bandar Lampung City considering the pandemic period and their relatively short distance to Lampung State Polytechnic. Data can be seen in Table 3 below.

Table 2. UMKM Data that becoming Research Subjects

\begin{tabular}{llc}
\hline No & District Names & Number of UMKMs \\
\hline 1 & Kedaton & 2.086 \\
2 & Rajabasa & 1.949 \\
\hline & Number of UMKMs in Bandar Lampung City & 4.035 \\
\hline
\end{tabular}

Source: Lakip Diskoperindag of Bandar Lampung City, 2016.

\subsection{Population and Sample}

Based on table 3, the population taken in this study is all of these UMKMs, namely 4,035. Researchers set a sample of $5 \%$ of the population so that a sample of 202 respondents can be obtained. Of the 202 UMKMs that were given questionnaires, only 152 UMKMs returned the questionnaires. The respondent's type of business can be seen in Table 4 below.

Table 3. Respondent's Type of Business

\begin{tabular}{llccc}
\hline No & Respondent's Type of Business & Kedaton & Rajabasa & Total \\
\hline 1 & Culinary & 22 & 29 & 71 \\
2 & Service & 12 & 24 & 36 \\
3 & Trade & 17 & 7 & 24 \\
4 & Production & 2 & 19 & 21 \\
\hline & Total & 53 & 99 & 152 \\
\hline
\end{tabular}

Furthermore, of the 152 questionnaires, only 111 questionnaires were filled and usable for the research.

\subsection{Aspects measured Research Implementation}

The aspects measured in this study are the taxpayers' understanding of the e-filing system, the ease of taxpayers' application of e-filing, and tax compliance. Based on research conducted by Solikah and Kusumaningtyas (2017), Wibisono, and Agus (2015), Measurement of Compliance Based on Minister of Finance Regulation Number 192 / PMK.03 / 2007 and Firdaus (2019).

1. Taxpayer's understanding of the e-filing system, seeing the taxpayer's understanding of the efiling system, seen from the relevant, informative, information format that is easy to understand, the content or components of the e-filing system.

2. Ease of taxpayers in applying e-filing, display that is clear and easy to learn in the sense that taxpayers do not need to bother, spend large amounts of time and funds in using it, especially in submitting Annual Tax Returns. 
3. Tax compliance, seen from the taxpayer who is timely in submitting the notification letter, there is no tax arrears, unless he has obtained permission to pay taxes in installments or postpone, has never been sentenced for committing criminal acts in the field of taxation within the last five years.

\subsection{Data Collection Techniques}

Data collection was carried out using Field Research, that is the data was obtained directly from respondents in the form of a questionnaire about the understanding and ease of using e-filing and taxpayer compliance, which was filled out by UMKMs in Bandar Lampung City. Measurement of variables in this study used an interval scale with a Likert scale type measurement. The questionnaire adopted the one in Firdaus' research (2019) which has been adjusted. Based on the data quality test, namely the Test of Validity and the Test of Reliability, the coefficient is greater than or equal to 0.30 and the coefficient is greater than 0.70 so that the instrument is considered valid or suitable for use and the coefficient is declared reliable

2.5. Data analysis method

Data analysis is based on the descriptive test, seen from how many respondents pay taxes using efiling applications.

\section{Results and Discussion}

UMKMs were given 202 questionnaires. The number of returned questionnaires was 152 . Only 111 questionnaires were filled and could be used. Data can be seen in table 4 .

Table 4. Respondent Characteristics

\begin{tabular}{|c|c|c|c|}
\hline No & Information & Subtotal & Total \\
\hline \multirow[t]{7}{*}{1} & Respondent level of education & & \\
\hline & Primary school (SD) & 05 & \\
\hline & Junior high school (SMP) & 13 & \\
\hline & Senior high school (SMA/SMEA/STM/SMK/D1) & 43 & \\
\hline & Diploma 3 (D3) & 00 & \\
\hline & Bachelor's degree (S1) & 42 & \\
\hline & Master's degree (S2) & 08 & 111 \\
\hline \multirow[t]{5}{*}{2} & Age & & \\
\hline & $20-30$ years & 30 & \\
\hline & $31-40$ years & 31 & \\
\hline & $41-50$ years & 29 & \\
\hline & $51-60$ years & 21 & 111 \\
\hline \multirow[t]{3}{*}{3} & Sex & & \\
\hline & Male & 64 & \\
\hline & Female & 47 & 111 \\
\hline \multirow[t]{6}{*}{4} & Length of Business & & \\
\hline & $0-1$ year & 11 & \\
\hline & $1-3$ years & 33 & \\
\hline & $3-5$ years & 30 & \\
\hline & More than 5 years & 16 & \\
\hline & More than 10 years & 21 & 111 \\
\hline \multirow[t]{5}{*}{5} & Number of employees & & \\
\hline & $1-5$ personnel & 66 & \\
\hline & $6-10$ personnel & 30 & \\
\hline & $11-20$ personnel & 12 & \\
\hline & $21-50$ personnel & 07 & \\
\hline
\end{tabular}


6

More than 50 personnel

Respondent Turnover

$<500.000$

$500.001-1.500 .000$

$1.500 .001-5.000 .000$

$5.000 .001-8.500 .000$

$>8.500 .001$

7

NPWP ownership

owns NPWP

Do not own NPWP

8

Use of e-filling in reporting taxes

Use

Do not use
00

49

31

20

07

04

90

21

65

46
111

111

Source: Processed data, 2020

Table 4 illustrates that the education of respondents varies widely, of the 111 respondents, mostly are SMA / K, and D1, namely 43 respondents, SD 5 respondents, SMP 13 respondents, D3 0 respondents, S1 42 respondents, and S2 8 respondents. Most respondents are in the range of $31-40$ years, namely 31 respondents, followed by 30 respondents aged 20-30 years, 29 respondents aged 41 50 years, and finally, 21 respondents aged 51-60 years. Of the 111 respondents, the largest proportion is male as many as 64 respondents and female respondents as many as 47 respondents.

The length of the respondent's business is mostly 1-3 years, namely 33 respondents, 3-5 years as many as 30 respondents, more than 10 years as many as 21 respondents, more than 5 years as many as 16 respondents, and 0-1 year as many as 11 respondents. Of the 111 respondents, 66 respondents had 1-5 employees, 30 respondents had 6-10 employees, 13 respondents had 11-20 employees, 7 respondents had 21-50 employees, and none has more than 50 employees.

Of the 111 respondents, 49 respondents had a turnover of $<$ IDR 500,000 per day, 31 respondents had a turnover of IDR 500,001 - IDR 1,500,000, 20 respondents had a turnover of IDR 1,500,001 IDR 5,000,000, 7 respondents had a turnover of IDR 5,000,001 - IDR 8,500,000, 4 respondents had a turnover of $>$ IDR $8,500,001$ per day.

Of the 111 respondents, 90 respondents had NPWP and 21 respondents did not have NPWP. And those who reported their taxes using e-filing were 65 respondents, and those who reported their taxes but did not use e-filing were 46 respondents. Of the 111 respondents who stated that they understood the e-filing system, there were as many as 106 respondents, who stated that it was easy to implement e-filing as many as 99 respondents. For tax compliance, 23 respondents paid taxes late but overall had complied with paying taxes.

\section{Conclusion}

Based on the results of calculations and discussion to see how the description of UMKMs in Bandar Lampung City use e-filing in paying taxes during the Covid-19 pandemic, it can be concluded that out of 111 respondents, 65 reported their taxes using e-filing and the remaining 46 respondents did not use e-filing. 106 respondents stated that they understand e-filing, 79 respondents stated that it is easy to use e-filing. For tax compliance, 23 respondents are late paying taxes but overall have complied with paying taxes. The Directorate General of Taxes should continue to disseminate information about efiling and ease of use so that it can increase taxpayer awareness of paying taxes and increase the use of e-filing in paying taxes.

\section{References}

[1] Anshori, Muslich and Sri Iswati. 2009. Quantitative Research Methodology. Center for Publishing and Printing Unair (AUP). Surabaya. 
[2] Damayanti. 2014. Land and Building Tax Revenues in Sukabumi District, Bandar Lampung City. ESAI Journal Vol.8 No.3 July 2014 Edition. ISSN No. 19786034. https://jurnal.polinela.ac.id/index.php/ ESAI / article / view / 949. DOI: http://dx.doi.org/10.25181/esai.v8i3.949. Retrieved July 13, 2019.

[3] Damayanti, Eksa Ridwansyah and Nurmala. 2015. Analysis of Tax Avoidance Strategies in the Framework of Savings in WPOP Tax Payments. Senapati Proceedings of Bali State Polytechnic Campus, September. ISSN No. 978-602-99802-2-2.

[4] Firdaus, Arif Saewoni. 2019. Implementation of E-Filing on Individual Taxpayer Compliance in Submitting Annual Tax Return. Faculty of Economics and Business. Univ. Erlangga. Surabaya

[5] Daily Cash. 2013. Boost Taxes Through New Taxpayers. March 20.

[6] Kurniawan, brother. 2020. Has the tax incentive been effective during a pandemic? https://muda.kompas.id/baca/2020/08/05/insentif-pajak-di-masa-pandemi-sudah-efektifkah/. 5th August.

[7] Nurmala, Damayanti and Evi Yuniarti. 2019. the level of awareness of MSMEs in the city of Bandar Lampung in paying taxes. ESAI Journal Vol.14 No.1 January 2020 Edition. ISSN No. 19786034.

[8] Ridwansyah, Eksa and Damayanti. 2018. Analysis of the Use of the e-filing System in Annual SPT reporting Using the Technology Acceptance Model (TAM) Approach at KPP Pratama Tanjung Karang. Proceedings of the National Seminar on Agricultural Technology Development at Lampung State Polytechnic. October. ISBN 978-602-5730-68-0. https://jurnal.polinela.ac.id/index.php/PROSIDING/article/view/1140. DOI: http://dx.doi.org/10.25181/prosemnas.v2018i0.1140. Retrieved 20 March 2020.

[9] Situmorang, Patricia Mauli Bertha and Suryadi. 2019. The Influence of Taxpayer Awareness and the Application of E-Filing on Taxpayer Compliance (Studies on MSMEs registered at KPP Pratama Candisari Semarang). Journal of Business Administration Science. Volume. 6 No 4. October Edition.

[10] Solikah, Mar'atus and Diah Kusumaningtyas. 2017. E-Filing at the Kediri City Primary Tax Service Office. Journal of Economics, University of Kediri.

[11] Sugiyono. 2002. Business Research Methods, CV Alfabeta Publisher, Bandung.

[12] Umar, Husein. 2011. Applied Accounting Research Methods. Ghalia Indonesia. Jakarta.

[13] Wibisono, Lisa Tamara and Agus Arianto Toly. 2015. Factors Affecting Taxpayers' Interest in Using E-Filing in Surabaya. Tax \& Accounting Review, 4 (1): 1-15

[14] Widyadinata, Yovita and Agus Arianto Toly. 2014. The Effect of System Quality, Information Quality, Timeliness and Confidentiality on E-Filing User Taxpayer Satisfaction. Tax \& Accounting Review.

[15] Widiyasnesti, Sri and Mochamad Reno Reynaldi. 2016. Taxpayers' Interest Analysis in Using E-Filing Services Through the Technology Acceptance Model (TAM) Approach at KPP Pratama Purwakarta, Indonesian Management Journal. Volume 16 No. April 1 Edition.

[16] www.kumparan.com. 2018. Lampung Taxpayer Realization is still 69 Percent. Accessed February 26, 2020. .-------. 2016.

[17] MSME Monitoring Data in the City of Bandar Lampung by District. Lakip Diskoperindag Bandar Lampung City. 